\title{
Using citizen science for early detection of tree pests and diseases: perceptions of professional and public participants
}

\author{
Nidhi Gupta $\cdot$ David D. Slawson (1D) Andy J. Moffat
}

Received: 10 June 2021 / Accepted: 2 September 2021 / Published online: 22 September 2021

(C) The Author(s) 2021

\begin{abstract}
Early detection of new tree pests and diseases is a vital element of national strategies to prevent their establishment and spread into a country or region, based on the rationale that it increases the chances of successful eradication. Given the limited capacity and financial resources of most national plant protection authorities, the use of public participants has recently been explored in a range of citizen science projects for its ability to supplement official surveillance. However, little is known about the motivations, expectations and experiences of members of the public involved in such activities and even less about the views of professionals and officials. In this study, evidence was obtained from structured interviews with professionals and volunteers engaged in five projects related to tree health surveillance. Some differences were noted between the two groups with a greater focus on personal aspects by members of the public and on strategic and institutional aspects by
\end{abstract}

Supplementary Information The online version contains supplementary material available at https://doi.org/10.1007/ s10530-021-02631-3.

N. Gupta $\cdot$ D. D. Slawson $(\bowtie)$

Imperial College London,

South Kensington, London SW7 1NE, UK

e-mail: david.slawson@imperial.ac.uk

\section{A. J. Moffat}

Forest Research, Alice Holt Lodge, Farnham GU10 4LH, UK professionals. A striking feature was the agreement of the two groups that the projects had met or exceeded their expectations, and provided the proof of concept that tree health surveillance capacity can be increased by engaging and training citizens. Many participants shared concerns about the importance of securing both project longevity and volunteer participation over the long term. The paper discusses ways in which the motivations of tree health surveillance participants can be sustained over long periods with particular attention to recognition and reward.

Keywords Citizen science · Tree health · Invasive pests and pathogens · Policy · Perceptions ·

Motivations $\cdot$ Recognition $\cdot$ Reward

\section{Introduction}

Worldwide, trees and forests are increasingly under threat from invasive non-native pests and diseases (FAO 2020). Many pathogens have been linked to global plant trade and the continued use of wood packaging for transporting materials (Eyre et al. 2013; Liebhold et al. 2012; Webber 2010). The effects of climate change have also increased the risk of pest establishment, spread and impact. Resulting outbreaks inflict serious ecological and economic damage (Aukema et al. 2011; Boyd et al. 2013). Early 
detection, surveillance and monitoring mechanisms facilitate more rapid and appropriate tree health management responses such as eradication, containment or control to help reduce or control the negative impact of pests and diseases (FAO 2018).

Until recently, major UK surveillance programmes have been undertaken by government agencies such as the Forestry Commission (FC) and Defra's Plant Health and Seeds Inspectorate. These involve a limited set of professionals (Slawson and Moffat 2020), primarily plant health specialists such as public sector inspectors and foresters, risk analysts, and regulatory scientists (Potter et al. 2011). In the face of the potentially large geographical scale of pest and disease spread across trees, woods and forests, in commercial forestry settings but also the wider environment, the UK regulatory bodies have limited institutional capacity and financial resources to provide effective tree health surveillance. People engaged professionally with trees, and the general public, offer a potential means to enhance the limited official surveillance capacity. This thinking is exemplified in several government strategy documents (Defra and Forestry Commission 2011; Defra 2014). Both reports led to citizen science (CS) being explored as a solution for the detection and surveillance of alien tree pests and diseases by engaging the public to support government agency staff.

Citizen Science: public participation

in environmental research

CS has been conventionally defined as public participation in research organised by professional scientists, wherein public participants either collect and or analyze data (Bonney et al. 2009; Dickinson and Bonney 2012). It is not a new concept; especially in the UK where there is a long history of public participation in environmental monitoring dating back as early as 17 th century. Then volunteers were recruited by scientists to contribute to natural history observations (Dickinson et al. 2012; Greenwood 2007). In recent times, technological innovations such as smartphones, the internet and GIS-enabled web applications have facilitated the participation of the public in CS projects (Nowak et al. 2020).

CS projects can be beneficial for both researchers and volunteers if effectively planned and managed, as researchers can gain long time series of data with wide spatial coverage and volunteers can learn new skills and become inspired about science (Bonney et al. 2009). Such projects can be a low-cost option for data collection that would otherwise be too expensive or time-consuming to be collected solely by contracted professionals (Roy et al. 2012). They also tap into and leverage the local knowledge and natural history expertise of volunteers (Conrad and Daoust 2008). The potential benefits of CS extend beyond science, as it offers public engagement with the environment, and potentially leads to increased scientific and environmental literacy and behavioural change (McKinley et al. 2017). It also fosters partnerships between scientists and local people (Toomey and Domroese 2013) and civic partnerships with the government (Fritz et al. 2019; Hecker et al. 2019). Many CS projects have involved monitoring biodiversity, establishing ecological or environmental baselines (Bell et al. 2008) and reporting plant phenology (Fuccillo et al. 2015). They have also been used in surveillance and documentation of novel pests and pathogens (Froud et al. 2008; Hulbert et al. 2017; Meentemeyer et al. 2015), and identification of host resistance in pest-invaded forests (Ingwell and Preisser 2011).

Citizen science through the lens of tree health in the UK

In 2012, the first discovery of Hymenoscyphus fraxineus on ash (Fraxinus excelsior) in the UK (Sansford 2013) generated extensive media comment and significantly raised the public and political profile of tree health (Urquhart et al. 2017). Around the same time, a number of CS projects were set up to seek public support for tree health surveillance. Two major CS tree health projects initiated by the UK government were Observatree and OPAL (Open Air Laboratories). Where tree health CS differs from many of the other fields of CS activity is that the citizen observations not only contribute towards government's statutory surveillance obligations but that the observations are needed in 'real-time'. An observation of a tree pest that is new to a country will trigger immediate official action to verify the observation and to justify control measures aimed at eradicating the incursion. For this reason, tree health CS projects present a unique case of enquiry into the views from both the volunteers and scientists involved. 
As CS is essentially a partnership between professional scientists and amateur volunteers in scientific research (Miller-Rushing et al. 2012), it is important to identify and analyse the attitudes, motivations and experiences of these stakeholder groups to help design more effective and harmonised tree health CS projects. To improve a project's delivery, professionals need a sound understanding of volunteers' expectations, motivations and experiences (Conrad and Hilchey 2011; Geoghegan et al. 2016; Land-Zandstra et al. 2016). Previous studies have shown that when volunteers perceive their motivations are 'in sync' with the benefits they experience by participating in the project, they are likely to be satisfied and willing to continue their volunteering task (Clary and Snyder 1999; O'Brien et al. 2008). Therefore, it is essential to take volunteer motivations into account in project design (Shirk et al. 2012). A thorough understanding of motivations can assist CS project managers in their understanding, recruitment and retention of volunteers (Bruyere and Rappe 2007). But there is also a need to understand what professional scientists think about the CS projects in which they are involved (Riesch and Potter 2014), as their views are likely to influence future design and delivery too (Conrad and Hilchey 2011; Henderson 2012). Wehn and Almomani (2019) also suggested the need to understand non-volunteer stakeholder groups, as their belief systems are known to differ from that of volunteers and need separate attention, especially related to CS practice and stakeholder engagement.

To date, studies investigating the opinions and motivations of participants in CS projects are limited in number (Skarlatidou et al. 2019) and research of Geoghegan et al. (2016), Mazumdar et al. (2017) and Phillips et al. (2018) represent some of the few studies which have examined specifically the views of professionals involved in CS. This paper presents a qualitative study of 46 interviews with the professionals and volunteers engaged in five projects on tree health or closely-related topics in the UK. The study investigates perceptions of professionals and volunteers involved in CS tree health projects and the different factors influencing their participation in them, their views on participating in their respective projects and the use of CS in general. Drawing from the main results of the study, the paper discusses a future roadmap for successful delivery of CS in tree health surveillance in Britain. We believe that our findings will be relevant to similar CS projects, given that these are now becoming evident elsewhere in the world (Brown et al. 2020). Specific research questions addressed in this paper are:

1. What pre-existing motivations and expectations of CS drive professional and volunteer participation?

2. To what extent did participation in CS fulfil participants' preconceptions?

3. What improvements are needed to maintain participants' long-term involvement in CS?

4. What is the potential for CS to generate evidence to inform policy and influence decision-making on environmental threats, such as tree health, facing society?

\section{Methodology}

Case studies

A case study approach was adopted to address the research questions as it provides a robust methodology to conduct in-depth investigation of a phenomenon within some specific context through various data sources (Yin 1984). Case study is one of the most frequently used methodologies in qualitative research as it allows for multi-perspective analyses of different stakeholder groups and the interaction between them (Tellis 1997). Five separate tree health CS projects were selected for study using the following criteria: each (a) should address a tree and/or tree health issue, or if not, engage participants with relevant observation and recording skills; (b) provides evidence to address a research and/or outreach need, where research might include monitoring and surveillance; (c) provides geographical coverage across the United Kingdom; and (d) the project manager was willing for their project to be selected. The case studies chosen were: (1) Observatree, a programme using members of the public trained to provide direct support to official surveillance for tree pests and diseases (Crow et al. 2020); (2) OPAL Tree Health Survey, an introductory survey for lay members of the public and school children to record pests and diseases of trees (Slawson and Moffat 2020); (3) National Plant Monitoring Scheme (NPMS), a long-term programme to monitor of changes in abundance of plant species (https:// www.npms.org.uk); (4) Ancient Tree Inventory 
(ATI), a living database of the UK's ancient and special trees (https://ati.woodlandtrust.org.uk/); and (5) Ceratocystis platani and Xylella fastidiosa Protected Zone Status Survey (2016), a survey in which trained people were involved professionally to survey specific plots across London for two specific tree pathogens.

Data collection and analysis

Participants were broadly categorised as professionals (project manager, scientist, policy lead) or volunteers. Participants were then contacted by email and appointments were agreed for interview. The professionals interviewed fulfilled various functions including project management (part of the project board and partner lead), high-level decision making, funding and promotion, volunteer recruitment, training and coordination, development of learning materials and reporting tools and database development and management. The roles undertaken by volunteers mostly involved surveying and reporting with some more expert volunteers providing verification and data quality checks.

Semi-structured telephone interviews were conducted between March and May 2017, each taking around 45-50 min to complete. Forty-six interviews were completed with 26 professionals and 20 volunteers involved in the five case study projects (Table 1). There were no volunteer interviews for two CS projects: the Ceratocystis platani and Xylella fastidiosa Protected Zone Status Survey 2016 (CSP) project did not involve any volunteers and for the Ancient Tree Inventory (ATP) project the volunteer details were not disclosed by the project staff who could be interviewed. Interviews were, with the participants' permission, recorded and fully transcribed.
The interview guide (Online Resource 1) was nearly the same for all the five CS projects, but some questions were added or deleted based on the unique characteristics of the project. Questions were grouped in order to explore participant motivations for and expectations from being engaged in CS projects; their attitudes to the projects in which they participated, in terms of the positive outcomes, perceived benefits associated with their involvement in these projects and the challenges they faced. Questions concerning the future needs and improvements in the projects as well as participants' opinions on the use of CS in general to address tree health policy were also explored in the interviews.

All transcriptions were imported into NVivo qualitative analysis software (QSR International, Doncaster, Australia) and coded to identify the emerging themes from the interviews. Coding was done by the first two authors and the emergent themes and subthemes were discussed among them to reach consensus on the main themes for further analysis. Top down coding was done using an a priori framework provided by the broad themes explored in the main interview questions: (a) Motivations and expectations; (b) Benefits and positive experiences; (c) Challenges and key improvements to increase effectiveness of CS approach; and (d) Future use of CS, specifically its utility to tree health policy. However, in the course of further analysis, additional subthemes also emerged that provided additional insights around the main themes and called for further classification. For example under the theme 'motivations', it was possible for these to be further classified into personal, environmental and social motivations. We recognise that these subthemes sometimes overlap and are not mutually exclusive. They can be considered a sequence rather than discrete outcomes. Once

Table 1 Case study interviews with professionals and volunteers

\begin{tabular}{lll}
\hline Name of the CS project & $\begin{array}{l}\text { No. of professional } \\
\text { interviews }\end{array}$ & $\begin{array}{l}\text { No. of volunteer } \\
\text { interviews }\end{array}$ \\
\hline Observatree & 9 & 8 \\
OPAL & 6 & 6 \\
National Plant Monitoring Scheme (NPMS) & 3 & 6 \\
Ancient Tree Inventory (ATP) & 3 & 0 \\
Ceratocystis platani and Xylella fastidiosa Protected Zone Status Survey & 5 & 0 \\
$\quad 2016$ (CSP) & & \\
\hline
\end{tabular}


the themes and subthemes were finalised, we looked for how often certain sentiments were expressed to draw out our main conclusions.

\section{Results}

Interview responses are presented below according to the main interview questions of (a) Motivations and expectations; (b) Benefits and positive experiences; (c) Challenges and key improvements to increase effectiveness of CS approach; and (d) Future use of CS, specifically its utility to tree health policy. In the tables below, statements have been drafted as a device to communicate succinctly the common themes to emerge from comments made by five or more interviewees. Those raised by both professionals and volunteers are attributed $(\mathbf{P \& V})$, those raised only by volunteers $(\mathbf{V})$ and those raised only by professionals (P). Where appropriate, direct quotes are used to support the summary statements. In addition, key similarities and differences between responses made by professionals and volunteers are highlighted.

(a) Motivations and expectations.

Professionals and volunteers expressed very similar motivations and expectations of their participation in CS projects (Table 2). Individuals in both groups expressed their desire to play their part in a national effort to protect the environment, specifically that data from their observations would be used to protect trees from new pest and disease threats:

My continued motivation is the fact that early detection and early management will hopefully allow some sort of protection of some of our important trees that provide great social and economic benefits and assets. (Volunteer).

They were driven by an existing interest in nature, in a specific subject or often in an individual species, which also meant they had the chance to be outside more. They wanted not only to increase their own knowledge and skills, but to share their passion with local communities as a means of engaging the wider public with the issue. In return, they sought appreciation and recognition for their efforts. In addition, professionals articulated their motivations and expectations in relation to specific national strategies, such as increased public engagement or to test the concept of $\mathrm{CS}$ as a means to address shortages of staff and funding.

Eighty-nine per cent of professional and volunteer interviewees stated that the project they had participated in had either exceeded or lived up to their expectations. Overall, professionals (96\%) suggested that projects met or exceeded expectations compared to volunteers $(80 \%)$. Only three (one professional and two volunteers) interviewees thought the project had failed to do so, with another two volunteers stating that it was too early to judge.

Table 2 Motivations and expectations common to both professional and volunteer groups

\begin{tabular}{|c|c|}
\hline Motivation/expectation type & Behaviour \\
\hline Personal motivations & Be outdoors \\
\hline Social motivations & Share knowledge with others, help volunteers, work with people and local communities \\
\hline Environmental motivations & $\begin{array}{l}\text { Prior interest in the environment, often in particular subjects, e.g. wildflowers, ancient trees, pest } \\
\text { and diseases } \\
\text { Educational or professional background in life sciences and the environment }\end{array}$ \\
\hline Personal expectations & $\begin{array}{l}\text { Make a valuable contribution to the activity } \\
\text { Be appreciated, recognised and feel valued for that contribution }\end{array}$ \\
\hline $\begin{array}{l}\text { Professional/organisational } \\
\text { expectations }\end{array}$ & $\begin{array}{l}\text { Give and receive feedback } \\
\text { Gain new skills and/or knowledge }\end{array}$ \\
\hline Environmental expectations & $\begin{array}{l}\text { Generate useful data and information } \\
\text { See that the data are being used } \\
\text { Feel a sense of contributing to the environment and to society } \\
\text { Prevent a pest/disease outbreak }\end{array}$ \\
\hline
\end{tabular}




\section{(b) Perceived Benefits}

A range of benefits and positive outcomes were cited as reasons for projects meeting or exceeding expectations (Table 3). As with 'Motivations and expectations', professionals and volunteers provided very similar feedback on perceived benefits and positive experiences from projects. Both groups recognised the contribution CS made to raise public awareness, promote public engagement on environmental issues and change attitudes and to help participants acquire new skills and knowledge:

I'm a little bit more active in voicing my concerns over issues to do with the environment. I comment on things and have an opinion on things that in the past I would have scrolled through and not maybe paid attention to, so yeah, it has definitely changed my attitude.

(Volunteer).

Volunteers praised the quality of the professional training and resources to help them gain technical skills on species identification of trees, pests and diseases, botany, map reading, biosecurity and sampling and testing. Professionals acknowledged that engaging with volunteers had broadened their own knowledge and help them develop their communication skills and management of projects, stakeholders and volunteers. Both groups also commented on the social benefits resulting from their participation, such as increased social interactions, more chances to meet new people and enhanced networking. They also reported benefits to their health and well-being, including boosted confidence, positive self-image, a feel-good factor and enjoyment. Only volunteers

Table 3 Perceived benefits and positive outcomes

\section{Professionals and volunteers}

\begin{tabular}{|c|c|}
\hline \multirow[t]{4}{*}{ Personal benefits } & $\begin{array}{l}\text { Increased knowledge and developed new skills, e.g. in volunteer management, project management, species } \\
\text { identification, sampling and testing techniques }\end{array}$ \\
\hline & Experienced enjoyment \\
\hline & Increased awareness about the role of volunteering \\
\hline & Felt positive from doing something worthwhile \\
\hline Social benefits & Improved attitude towards environment in general \\
\hline $\begin{array}{l}\text { Personal } \\
\text { outcomes }\end{array}$ & $\begin{array}{l}\text { Increased knowledge and understanding of tree health, woodlands, and identification of species (plants, pests and } \\
\text { pathogens) } \\
\text { Increased social interactions from meeting and working with new 'like-minded' people }\end{array}$ \\
\hline \multirow[t]{4}{*}{ Project outcomes } & $\begin{array}{l}\text { Trees better protected from pests and diseases as a result of increased monitoring, early detection and more } \\
\text { timely control measures }\end{array}$ \\
\hline & $\begin{array}{l}\text { Volunteers' capability increased through design and development of high-quality identification guides, materials } \\
\text { and courses }\end{array}$ \\
\hline & $\begin{array}{l}\text { Continued engagement of volunteers is dependent on provision of effective support and regular contact, } \\
\text { communications and feedback }\end{array}$ \\
\hline & $\begin{array}{l}\text { Public (including school children) more interested, aware and engaged with trees at a local level, and with an } \\
\text { improved attitude towards the environment }\end{array}$ \\
\hline \multicolumn{2}{|l|}{ Professionals only } \\
\hline \multirow[t]{2}{*}{$\begin{array}{l}\text { Professional } \\
\text { benefits }\end{array}$} & $\begin{array}{l}\text { Connections to and collaboration with other organisations and institutions nationally and internationally have } \\
\text { been enhanced }\end{array}$ \\
\hline & The case for future partnership working has been strengthened \\
\hline Social benefits & Enhanced 'networking' \\
\hline \multirow[t]{5}{*}{ Project outcomes } & A surveillance network of enthusiastic, committed and trained volunteers has been established and maintained \\
\hline & Wider communities have been engaged through the volunteer network \\
\hline & Trust and working relationships between project partners have improved \\
\hline & A large amount of robust, high quality data and scientific outputs have been generated \\
\hline & $\begin{array}{l}\text { The proof of concept has been demonstrated that the general public can be trained to observe and report tree pests } \\
\text { and diseases }\end{array}$ \\
\hline
\end{tabular}


commented on the positive feelings associated with contributing something useful:

I think in some ways citizen science leaves you feeling like you're feeding into something that has greater worth and you're feeding into a much bigger picture. (Volunteer).

Some themes raised only by professionals related to their professional lives. These included, collaboration, partnership working and relationship development, including internationally. Professionals also praised the enthusiasm and commitment of volunteers and stressed value of the data they generated, in effect to provide proof of concept that citizens can contribute to official surveillance:

....at the beginning, we were literally just thinking of putting dots on a map, ....but it's just moved on so much from that, ... we now have large government organisations ... really looking seriously at the data we've got, and how that can influence some of their policies, certainly on the protection of trees, and the landscapes around those trees, that's really, really inspiring, and that certainly wasn't really considered or thought about at the beginning. (Professional).

\section{(c) Challenges and improvements.}

Interviewees expressed views on the challenges and problems encountered in their participation in CS projects and made suggestions on improvements needed to maintain their long-term involvement, and that of others. In Table 4, responses have been further grouped into broad common themes of: (i) Resourcing and supporting volunteers; (ii) IT infrastructure (databases, websites etc.); (iii) Data quality; (iv) Use and uptake by policymakers; and (v) Funding and sustainability. Although commonly-expressed views have been categorised into these broad themes, it is important to note that many suggested improvements will have effects across other themes. For example, provision of training and quality survey guides will aid data quality and allocating specific tasks to more expert volunteers and more focused monitoring of specific sites will aid both data quality and value of evidence for policymakers:
Targeted recruitment ... I feel that that might allow a better product if we had a proper, reasonably well distributed network of volunteers, you wouldn't get black holes in areas and massively over-reported areas in most places. (Professional).

Another question in regard to participants' perceptions of their CS projects was whether or not projects should continue and for what reason. Overall, 96\% affirmed the need for their projects to continue. The main reason cited to support continuation was that the environmental challenges have not gone away, which means that there is a continued need for data:

I think to stop something like this would be wrong. It's not a whim, it's an absolutely need, for our future and our children's futures... that we do this research. (Volunteer).

Raising the public's awareness of environmental issues, introducing the next generation to nature and not wasting the investment made in engaging, training and supporting CS networks were also cited as reasons for projects to continue. Although volunteers wanted projects to continue, it was notable that only professionals commented specifically on funding and sustainability of projects.

(d) Future use of citizen science and its utility to tree health policy

Finally, volunteers and professionals expressed consistent views on the strategic value of citizen science to tree health, including increased capacity to complement official surveillance, increased chances of early detection, benefits of volunteers' local knowledge and expertise and, if verified, potential for data to influence policy and decision-making (Table 5). Increased awareness of trees and tree health was recognised as a valued side-effect of an engaged and trained public:

I think we're seeing that non-experts are actually really quite good and really quite interested, so as long as there are proper mechanisms to check the data quality then absolutely there's a role for citizen science. (Professional).

You haven't got many expert plant pathologists. But a lot of people with some very basic training could report those sort of diseases. (Volunteer). 
Table 4 Challenges and improvements

(i) Resourcing and supporting volunteers

\section{Challenges}

Time constraints and adverse effect on 'work-life balance' (P\&V)

Seasonality of tree health surveys which limits their use and popularity $(\mathbf{P \& V})$

Difficulties in volunteer recruitment to create a robust national platform (one project only) (P)

Disappointment associated with not finding any pests (V)

Improvements

Recruit more volunteers (P)

Broaden the awareness of projects to general public (P)

Find better ways to make the projects appealing to the younger generation $(\mathbf{P})$

Arrange (more) training workshops (P)

Make survey guides simpler and keep updated (P)

Allocate specific tasks to good volunteers, e.g. verification (P)

Increase the focus of monitoring in specific sites (P)

Adopt an accreditation/recognition system to reward volunteers for their level of expertise attained (P)

Build local/regional volunteer networks with lead volunteers supporting and mentoring other volunteers in their local area (P)

Facilitate networking between volunteers, e.g. through short- or one-day courses and field studies/surveys to boost confidence (V)

Manage expectations of the volunteers (P)

Focus surveys to appropriate times of the year $(\mathbf{P} \& \mathbf{V})$

Seek to engage and involve participation of people with existing knowledge and skills, e.g. tree officers, foresters, conservation wardens $(\mathbf{P})$

Improve geographical coverage of volunteers where needed $(\mathbf{P})$

(ii) IT infrastructure (databases, websites etc.)

\section{Challenges}

Difficulty in recording submissions on the computer/website $(\mathbf{P \& V})$

Problems uploading and saving information/data (P\&V)

Website does not engage people $(\mathbf{P \& V})$

Improvements

Ensure website is functional with respect to its role in data entry, transfer etc. (P\&V)

Provide IT support to users (P\&V)

Provide clear and definite guidelines on data collection and submission $(\mathbf{P \& V})$

Simplify and streamline processes $(\mathbf{P})$

Keep data records up to date $\mathbf{( P )}$

(iii) Use and uptake by policymakers

\section{Challenges}

Inadequate communication of results and outcomes beyond professional audiences or sharing of best practice e.g. to other countries (one project only) (P)

\section{Improvements}

Increase the value of the data to the policymaker e.g. produce summaries, link the evidence to national/local policy needs $(\mathbf{P})$

Promote the findings and tangible benefits of the project to funding organisations (P)

Involve policymakers in co-design of CS projects $(\mathbf{P})$

Increase communications about the projects to external stakeholders (P)

Project extension - Increased collaboration needed between different tree or other CS projects and expansion of the project across UK and internationally $(\mathbf{P})$

Repeat the surveys on the same site over time to collect longitudinal data $(\mathbf{P} \& \mathbf{V})$ 
Table 4 continued

(iii) Use and uptake by policymakers

Perform more targeted surveys (more focused on sites and issues rather than individual discretions $(\mathbf{P \& V})$

(iv) Funding and sustainability

\section{Challenges}

Limited funding (P)

Reliance on grant funding (P)

Challenges to continue the project after the end of funding or to run the project with limited amount of money and capacity (P)

Improvements

More resources needed - funding and staff time (P)

Understand better the needs of policy makers (P)

Better embed CS concept within government (P)

Table 5 Views on citizen science in tree health

Increases surveillance capacity achievable by officials alone (V)

Increases chances of early detection $(\mathbf{P \& V})$

Builds public awareness (P\&V)

Supports local level involvement, data collection and taps into local knowledge and expertise (P\&V)

Generates reliable data if collected responsibly, verified by an expert and any limitations are clearly understood (P\&V)

Contribute evidence to influence tree health policy and inform decision-making on control and mitigation of pests (P\&V)

\section{Discussion}

Biological recording has always relied upon citizen scientists, well before the adoption of the term (Cohn 2008), but the use of CS in support of government surveillance for pest and pathogen species included in national plant health legislation is relatively novel (Slawson and Moffat 2020). The purpose of this study was to better understand the motivations, expectations and experiences of both public and professional participants engaged in some of the CS projects aimed at enhancing official surveillance of tree pests and diseases. Recent reviews of CS perceptions and motivations (e.g. Encarnação et al. 2021; Ganzevoort et al. 2017) have focused on volunteers. In contrast, feedback from government officials, including scientists, policymakers and operations managers, was of particular interest given both the nascent status of tree health CS and the relative paucity of literature on the views of professionals compared to public participants from more established fields of CS research.

For such a fledgling activity as use of CS to support official tree health surveillance, the results that nearly $90 \%$ of interviewees reported that projects met or exceeded their expectations and 96\% recommended that the CS approach should continue to be used, was astonishing. There was overwhelming 'proof of concept' feedback to confirm that a CS approach can be an effective means to enhance official surveillance, a result of significant value to policymakers and funders. Irwin and Michael (2003) have stressed the importance of utilizing lay knowledge at the local level, and our respondents took a similar view in supporting the deployment of CS surveyors in the localities in which they lived. In the context of tree health, CS observers are likely to be more diligent than those brought in from outside the neighbourhood as they are likely to have valuable knowledge based on experience of 
living there, and a desire to help prevent the spread of a tree pest of disease as far as their interventions allow this to happen.

Numerous concerns were expressed about the longterm resourcing and sustainability of CS approaches to support government tree health surveillance. Comments were made that it would be "a shame", "a waste on investment" or simply "wrong" to stop, to "lose momentum" and not build on progress made. Funding and sustainability of CS projects remains one of the most critical concerns of CS practitioners (Hecker et al. 2018). Closer involvement of policymakers and scientists at all stages of the projects, from defining the objective, designing the activity to championing the benefits and impacts, was deemed essential by our respondents. This is congruent with previous studies that identified policy as a major beneficiary of CS and advocated for more direct involvement of the policy makers in CS initiatives (European Commission 2020; Pocock et al. 2019; Schade et al. 2021). To counter the risks of project cessation, suggestions were made to mainstream or embed CS into official surveillance programmes, with funding coming from programme budgets and for the CS activity to complement and contribute towards official targets. Progress has been made elsewhere in these respects. In the USA, for example, the Crowdsourcing and Citizen Science Act (2017) encourages government agencies to use CS approaches to help fulfil their missions, a White House memorandum requires them to appoint responsible officers and to report on their progress on an annual basis, with support from the Federal Crowd Sourcing and Citizen Science Digital Platform. In the European Union, Action 8 of the "EC Action Plan for Environmental Reporting" (European Commission 2017) promotes the wider use of CS to complement environmental reporting. Guidelines have been published on how CS for environmental monitoring and reporting can be applied and mainstreamed in policy making at EU level. In the UK, one of the case-study projects we studied, Observatree, received 50\% funding from the EU's LIFE Programme from 2013 to 2017. Since then, however, it has been funded by project partners including the Department for Environment, Food and Rural Affairs (Defra), the UK Government Department with responsibility for tree health (Crow et al. 2020). In 2021, it was awarded a further five years funding, and has, in effect, become part of the country's tree health surveillance system.
Some of the reported benefits of the CS projects we studied related directly to the objectives of the respective project whilst others could be described as 'indirect' benefits, derived more broadly from CS project participation. 'Direct' benefits included generation of useful data from suitably trained volunteers and increased capability and capacity amongst them. Findings of oriental chestnut gall wasp and oak processionary moth (both pests included in plant health legislation) were mentioned by professionals and volunteers as evidence of a functioning surveillance network which generated evidence on current pest distribution and enabled official action to be taken to prevent further spread. Pocock et al. (2017) also found that CS can be especially powerful in tackling geographically extensive problems such as detecting rare species or documenting the establishment of invasive species. Underpinning this increase in public capability is the acquisition of new skills and knowledge, which both satisfies a motivational need driving the public's participation and delivers a government objective for a more scientifically-literate public. In addition, learning was recognised as a two-way process with professionals expressing amazement at how much their own technical knowledge, general management skills and network of contacts had grown from working with the public. This emphasises the importance and advantages of engaging local community members as they facilitate the understanding of the social contexts and public priorities among participating managers, scientists, regulators and decision makers, as has been found by others (e.g. McKinley et al. 2012; Stepenuck and Green 2015).

'Indirect' benefits included members of the public reporting that they were more engaged with, and aware of, environmental issues, and more committed to environmental stewardship. Participants also reported benefits to their own social, health and well-being. Such benefits appear to have accrued despite the lack of formal decision-making regarding their inclusion as planned outcomes of the studies in question. Lakeman-Fraser et al. (2016) suggested that there needs to be clarity of purpose - is the aim of the CS activity data generation, public engagement, or both? In the design phase of tree health projects intended to support government surveillance, it is important to decide to what extent public engagement is an important outcome, or whether the focus should be on tree protection. Our study suggests that retaining 
the ability to deliver both is likely to help in volunteer retention and their overall satisfaction in project participation. Suitable metrics are needed to measure these 'indirect' benefits so that the full impact of a CS approach can be determined.

An important point that emerged about motivation of the public in our study was that it is easily lost without continued support and nurturing. Potter et al. (2011) reported that although public awareness is high when tree diseases feature heavily in the national media, that interest, concern and willingness to engage declines over time. For this reason, once a cadre of volunteers has been engaged successfully in a project, continued effort is needed to maintain their involvement. Our study supports these assertions, but also suggests that in the five projects examined in detail, project leaders were acutely aware of this issue and did much to motivate volunteers during the execution of the projects concerned. Nevertheless, if CS surveillance is to mature to become an official part of government tree health policy, higher level programme planning should mitigate the risk of personnel loss as far as possible. This is a key finding of our project. In terms of volunteer motivation, one of the interesting observations from our study is the notion of disappointment when a volunteer does not encounter a pest. Even though lack of sightings (null result) is a good silvicultural outcome, it can be experienced as demotivating for the volunteers. This is one of the ethical issues pertinent to tree health citizen science and resonates with the difficulty that biodiversity monitoring projects can have to stimulate citizen scientists to report null results. Emphasis should be given on their participation rather than finding a pest or disease and the importance of negative findings should be communicated to the volunteers. In future, these ethical issues need to be addressed directly in the development of CS projects on tree health, as it is vital to maintain volunteer's continuous support and trust in citizen science (Pocock et al. 2020).

A significant shared motivation in both professional and volunteer groups was the need for recognition. This need is not an unexpected one in respect of the volunteers interviewed as it is a recurrent theme in CS (Vohland et al. 2021). However, it was also expressed by several professional interviewees on behalf of the volunteer CS community that they had worked with. It appears fundamental that systems for recognising volunteer effort and expertise are built into CS projects at the planning stage, and that appropriate training is given to scientific personnel who may have little or no experience of working with lay folk. In addition, for volunteers who may be recruited into future tree health CS projects supporting government tree health surveillance, more formal mechanisms of recognition should be contemplated (a) to reward loyal volunteers appropriately, and (b) to maximise the likelihood of volunteer persistence in the project or programme. It may be appropriate to ensure that future budgets to support and maintain key personnel allow for reimbursement of expenses, notably for travel and subsistence and for Personal Protective Equipment (PPE), in a similar manner to those that support police volunteers in Britain (Home Office 2014). In addition, for those involved in government-backed programmes, provision of an 'Open Badge System' (Mozilla Corporation et al. 2012) or other form of recognition of service and proficiency should be considered, in order that volunteers can demonstrate this to other agencies as appropriate (e.g. when seeking new employment opportunities). In addition to recognition, feedback to volunteers on the data collected and its use remains to be an important driver for motivating the volunteers and recognising their efforts in the project. Maintaining motivation of volunteers via feedback (Singh et al. 2014; Unell and Castle 2012), rewards (Locke et al. 2003; O'Brien et al. 2010) or both can help in retaining the volunteers in the CS projects (West and Pateman 2016).

Within their areas of expertise, recognition and reputation were important concerns for tree health professionals too. This result accords with the work of Riesch and Potter (2014) in which research scientists stated that not only was CS not recognised in their institutions but that they feared that participation in CS might be harmful to their careers. In the intervening years, recognition of CS as a legitimate arm of scientific exploration has increased significantly, such that peer reviewed papers emanating from CS are cited to a similar degree to those that aren't (Odenwald 2020). In addition, there is a larger emphasis on research impact than previously, and properly organised, CS projects have the capacity to demonstrate this well (Kieslinger et al. 2018). Perhaps professionals have less to fear than was the case historically but this study demonstrates that scientific recognition remains an important consideration when planning similar tree health CS projects. 
Many suggestions were made on how similar projects could be improved (Table 4), and they provide invaluable advice for policymakers and scientists considering use of a tree health CS approach in the future. Whilst some suggestions have been made previously, such as provision of expert training, or a focus on quality assurance processes such as verification or triaging of reports by professionals or more expert members of the public, (MacKenzie et al. 2017; van der Wal et al. 2016; Young et al. 2019), other ideas were more novel. Firstly, the suggestion was made to engage volunteers with existing specialist tree knowledge and skills, such as local government tree officers, consultants and contractors. This is an approach that pushes some definitions of CS which refer only to members of the general public (Haklay et al. 2021) and may also act as a barrier for entry. However, it is an approach that has been used successfully in one of the case studies, Observatree. Recruitment of volunteers to the Observatree project includes an interview to assess their tree knowledge (Crow et al. 2020), and it identifies the recognition that for some CS projects or programmes it is necessary to evaluate the capacity of volunteers to perform duties asked of them, and even the likely quality of outputs that they will deliver. Secondly, concerns were expressed about the patchy geographical coverage of public observers, a problem that might be exacerbated if participants are required to have some tree knowledge. Increased collaboration with the wider biological recording community was suggested as one solution because local enthusiasts are often best-placed to detect environmental change, they have existing skills of identification and reporting, and they could be easily trained to identify selected tree pests and diseases.

Some of the approaches summarised above have been suggested before (Slawson and Moffat 2020) but to date have not been developed further. Clearly, they represent positions on a spectrum from, at one end, a 'workforce' of unskilled volunteers who give their time freely in support of an interest or cause to the other, of paid employees bound by employment contracts. To what extent movement away from a purely voluntary approach diverges from CS as it has been traditionally defined is a debatable point and one that brings ethical dimensions of potential exploitation. It seems evident that recruiting volunteers to fulfil roles that were previously occupied by professional staff should carry with it a proper appreciation of the need for recognition and just reward, and consideration of other rights customarily given to employees. As Citizen Science matures and 'comes of age' (Fitzpatrick 2015), it is now time to address these types of issues, especially where CS projects are designed to be an integral part of government policy delivery.

\section{Conclusions}

This study examined the personal motivations, expectations and experiences of both professional and public participants engaged in the relatively novel concept of publicly supported government surveillance of tree pests and diseases. Substantial testimony has shown that the Citizen Science approach was not only able to generate data of value to scientists and policymakers but also to raise awareness of environmental issues amongst the public, benefits which are often overlooked. Serious concerns were expressed that realization of the full potential of Citizen Science in support government surveillance will require greater integration of Citizen Science activity into government surveillance programmes and the development of more sustainable long-term funding models with appropriate mechanisms for recognition and reward.

Acknowledgements This paper is based on the knowledge and evidence generated under the research fellowship (Project No. P56834 / Defra Contract No. TH0147) funded by Department for Environment Food \& Rural Affairs (Defra), 2015-2018. We would like to acknowledge the assistance and support of the project leads/coordinators: Jake Morris (Defra); Peter Crow (Observatree); Hayley New (NPMS); John Parker (CSP); Kylie Harrison (ATI) who agreed to participate in the case study research reported in this paper. We would also like to thank Helen Jones from the Woodland Trust in recruiting interviewees and Susanne Raum for conducting additional interviews for the Observatree case study. Our deepest gratitude goes to all those professionals and volunteers who participated in the interviews. Without them this study would not have been possible. Finally, we thank the reviewers of the manuscript for their insightful and constructive advice.

Authors' contributions Funding acquisition was accomplished by David D Slawson. Nidhi Gupta and David D Slawson contributed to the study conception and design. Material preparation and data collection were performed by Nidhi Gupta. Analysis, writing, review and editing were carried out by all the authors. All authors read and approved the final manuscript. 
Funding This paper is based on the knowledge and evidence generated under the research fellowship (Project No. P56834 / Defra Contract No. TH0147) funded by Department for Environment Food \& Rural Affairs (Defra), UK, 2015-2018.

Availability of data and materials The datasets generated during and/or analysed during the current study are available from the corresponding author on reasonable request.

\section{Code availability Not Applicable.}

\section{Declarations}

Conflicts of interest The authors have no financial or proprietary interests in any material discussed in this article.

Ethics approval The research involves the use of educational tests, surveys, interview procedures or observations of public behaviour where participants cannot be identified in any way, and where they are at no risk of adverse treatment through participation (e.g. criminal investigation). "Informed consent" was also mentioned. Participation was entirely voluntary. Informed consents to participate and for publication of results (where participants cannot be identified in any way) were sought and received prior to commencement of interviews. Ethical approval was not required for this study due to its study design.

Consent to participate Full informed consent to participate was given by all interviewees before the interviews commenced.

Consent for publication Full informed consent for publication of results (where participants cannot be identified in any way) was given by all interviewees before the interviews commenced.

Open Access This article is licensed under a Creative Commons Attribution 4.0 International License, which permits use, sharing, adaptation, distribution and reproduction in any medium or format, as long as you give appropriate credit to the original author(s) and the source, provide a link to the Creative Commons licence, and indicate if changes were made. The images or other third party material in this article are included in the article's Creative Commons licence, unless indicated otherwise in a credit line to the material. If material is not included in the article's Creative Commons licence and your intended use is not permitted by statutory regulation or exceeds the permitted use, you will need to obtain permission directly from the copyright holder. To view a copy of this licence, visit http://creativecommons.org/licenses/by/4.0/.

\section{References}

Aukema JE, Leung B, Kovacs K et al (2011) Economic impacts of non-native forest insects in the continental United States. PLoS ONE 6(9):e24587. https://doi.org/10.1371/ journal.pone.0024587
Bell S, Marzano M, Cent J et al (2008) What counts? Volunteers and their organisations in the recording and monitoring of biodiversity. Biodivers Conserv 7:3443-3454. https://doi. org/10.1007/s10531-008-9357-9

Bonney R, Ballard H, Jordan R et al (2009) Public participation in scientific research: defining the field and assessing its potential for informal science education. Centre for Advancement of Informal Science Education (CAISE), Washington, DC

Boyd IL, Freer-Smith PH, Gilligan CA, Godfray HCJ (2013) The consequences of tree pests and diseases for ecosystem services. Science 342:823. https://doi.org/10.1126/science. 1235773

Brown N, Pérez-Sierra A, Crow P, Parnell S (2020) The role of passive surveillance and citizen science in plant health. CABI Agric Biosci 1:17. https://doi.org/10.1186/s43170020-00016-5

Bruyere B, Rappe S (2007) Identifying the motivations of environmental volunteers. J Environ Plan Manag 50(4):503-516. https://doi.org/10.1080/ 09640560701402034

Clary EG, Snyder M (1999) The motivations to volunteer: theoretical and practical considerations. Psychol Sci 8(5):156-159. https://doi.org/10.1111/1467-8721.00037

Cohn JP (2008) Citizen science: can volunteers do real research? Bioscience 58:192-197. https://doi.org/10.1641/B580303

Conrad CC, Hilchey KG (2011) A review of citizen science and community-based environmental monitoring: issues and opportunities. Environ Monit Assess 176:273-291. https:// doi.org/10.1007/s10661-010-1582-5

Conrad CT, Daoust T (2008) Community-based monitoring frameworks: increasing the effectiveness of environmental stewardship. Environ Manag 41:358-366. https://doi.org/ 10.1007/s00267-007-9042-x

Crow P, Perez-Sierra A, Kavčič A et al (2020) Using citizen science to monitor the spread of tree pests and diseases: outcomes of two projects in Slovenia and the UK. Manag Biol Invasion 11(4):703-719. https://doi.org/10.3391/mbi. 2020.11.4.06

Crowdsourcing and Citizen Science Act of 2017 (2017) https:// uscode.house.gov/view.xhtml?req=granuleid:USCprelim-title15-Secs. 3724\&num=0\&edition=prelim. Accessed 20 May 2021

Defra (2014) Making the most of our evidence: a strategy for Defra and its network. https://assets.publishing.service. gov.uk/government/uploads/system/uploads/attachment_ data/file/318610/evidence-strategy-defra.pdf. Accessed 20 May 2021

Defra and Forestry Commission (2011) Action plan for tree health and plant biosecurity. http://www.gov.uk/ government/uploads/system/uploads/attachment_data/file/ 69330/pb13657-tree-health-actionplan.pdf. Accessed 20 May 2021

Dickinson JL, Bonney R (2012) Citizen science: public participation in environmental research. Cornell University Press, Ithaca. https://doi.org/10.7591/cornell/ 9780801449116.001.0001

Dickinson JL, Shirk J, Bonter D et al (2012) The current state of citizen science as a tool for ecological research and public engagement. Front Ecol Environ 10(6):291-297. https:// doi.org/10.1890/110236 
Encarnação J, Teodósio MA, Morais P (2021) Citizen science and biological invasions: a review. Front Environ Sci 8:602980. https://doi.org/10.3389/fenvs.2020.602980

European Commission (2017) Action plan to streamline environmental reporting (COM(2017) 312), Brussels. https:// ec.europa.eu/environment/legal/reporting/pdf/action_ plan_env_issues.pdf. Accessed 26 May 2021

European Commission (2020) Best practices in citizen science for environmental monitoring. Commission Staff Working Document (SWD (2020) 149 final), Brussels. https://ec. europa.eu/environment/legal/reporting/pdf/best_ practices_citizen_science_environmental_monitoring.pdf. Accessed 20 May 2021

Eyre D, Anderson H, Baker R, Cannon R (2013) Insect pests of trees arriving and spreading in Europe. Outlooks Pest Manag 24(4):176-180. https://doi.org/10.1564/v24_aug_08

FAO (2018) International Standard for Phytosanitary Measures (ISPM) -6 Surveillance. https://www.ippc.int/en/ publications/615/. Accessed 13 August 2021

FAO (2020) Invasive species: impacts on forests and forestry. http://www.fao.org/forestry/aliens/en/. Accessed 26 May 2021

Fitzpatrick JW (2015) Afterword. In: Dickinson JL, Bonney RE (eds) Citizen science. Public participation in environmental research. Cornell University Press, Ithaca, pp 235-241

Fritz S, See L, Carlson T, Haklay M et al (2019) Citizen science and the United Nations Sustainable Development Goals. Nat Sustain 2:922-930. https://doi.org/10.1038/s41893019-0390-3

Froud K, Oliver T, Bingham P, Flynn A, Rowswell N (2008) Passive surveillance of new exotic pests and diseases in New Zealand. In: Surveillance for biosecurity: pre-border to pest management. New Zealand Plant Protection Society, Paihia, pp 97-110

Fuccillo KK, Crimmins TM, de Rivera CE, Elder TS (2015) Assessing accuracy in citizen science-based plant phenology monitoring. Int J Biometeorol 59:917-926. https://doi. org/10.1007/s00484-014-0892-7

Ganzevoort W, van den Born RJG, Halffman W et al (2017) Sharing biodiversity data: citizen scientists' concerns and motivations. Biodivers Conserv 26:2821-2837. https://doi. org/10.1007/s10531-017-1391-z

Geoghegan H, Dyke A, Pateman R et al (2016) Understanding motivations for citizen science. Final report on behalf of UKEOF. University of Reading, Stockholm Environment Institute (University of York) and University of the West of England, $120 \mathrm{pp}$

Greenwood JJD (2007) Citizens, science and bird conservation. J Ornithol 148:77-124. https://doi.org/10.1007/s10336007-0239-9

Haklay M, Dörler D, Heigl F et al (2021) What Is citizen science? The challenges of definition. In: $\mathrm{K}$ Vohland et al (eds), The science of citizen science, pp 13-33. https://doi. org/10.1007/978-3-030-58278-4_2

Hecker S, Haklay M, Bowser A et al (2018) Citizen science: innovation in open science, society and policy. UCL, London

Hecker S, Wicke N, Haklay M, Bonn A (2019) How does policy conceptualise citizen science? A qualitative content analysis of international policy documents. Citiz Sci Theory Pr 4(1):1-16. https://doi.org/10.5334/cstp.230
Henderson S (2012) Citizen science comes of age. Front Ecol Environ 10(6):283. https://doi.org/10.1890/1540-9295-10. 6.283

Home Office (2014) Home Office guidance on Special Constable expense and allowance rates. Police Integrity and Powers Unit, Home Office, London. https://assets. publishing.service.gov.uk/government/uploads/system/ uploads/attachment_data/file/304488/ GuidanceSpecialConstableExpenseAllowanceRates.pdf. Accessed 20 May 2021

Hulbert JM, Agne MC, Burgess TI et al (2017) Urban environments provide opportunities for early detections of Phytophthora invasions. Biol Invasions 19:3629-3644. https://doi.org/10.1007/s10530-017-1585-z

Ingwell LL, Preisser EL (2011) Using citizen science programs to identify host resistance in pest-invaded forests. Conserv Biol 25:182-188. https://doi.org/10.1111/j.1523-1739. 2010.01567.x

Irwin A, Michael M (2003) Science, social theory and public knowledge. Open University Press, Maidenhead

Khaliq I, Hardy GES, White D, Burgess TI (2018) eDNA from roots: a robust tool for determining Phytophthora communities in natural ecosystems. FEMS Microbiol Ecol 94:fiy048. https://doi.org/10.1093/femsec/fiy048

Kieslinger B, Schäfer T, Heigl F et al (2018) Evaluating citizen science. Towards an open framework. In: Hecker S, Haklay M, Bowser A, Makuch Z, Vogel J, Bonn A (eds) Citizen science: Innovation in open science, society and policy. UCL Press, London. http://discovery.ucl.ac.uk/10058422/ 1/Citizen-Science.pdf. Accessed 20 May 2021

Lakeman-Fraser P, Gosling L, Moffat AJ et al (2016) To have your citizen science cake and eat it? Delivering research and outreach through Open Air Laboratories (OPAL). BMC Ecol 16:16. https://doi.org/10.1186/s12898-0160065-0

Land-Zandstra AM, Devilee JLA, Snik F et al (2016) Citizen science on a smartphone: participants' motivations and learning. Public Underst Sci 25:45-60. https://doi.org/10. 1177/0963662515602406

Liebhold AM, Brockerhoff EG, Garrett LJ et al (2012) Live plant imports: the major pathway for forest insect and pathogen invasions of the US. Front Ecol Environ 10(3):135-143. https://doi.org/10.1890/110198

Locke M, Ellis A, Davis Smith J (2003) Hold on to what you've got: the volunteer retention literature. Voluntary Action 5(3):81-99

MacKenzie CM, Murray G, Primack R, Weihrauch D (2017) Lessons from citizen science: assessing volunteer-collected plant phenology data with Mountain Watch. Biol Conserv 208:121-126. https://doi.org/10.1016/j.biocon. 2016.07.027

Mazumdar S, Wrigley S, Ciravegna F (2017) Citizen science and crowdsourcing for earth observations: An analysis of stakeholder opinions on the present and future. Remote Sens 9(1):87. https://doi.org/10.3390/rs9010087

McKinley DC, Briggs RD, Bartuska AM (2012) When peerreviewed publications are not enough! Delivering science for natural resource management. Forest Policy Econ 21:1-11. https://doi.org/10.1016/j.forpol.2012.03.007

McKinley DC, Miller-Rushing A, Ballard H et al (2017) Citizen science can improve conservation science, natural resource 
management, and environmental protection. Biol Conserv 208:15-28. https://doi.org/10.1016/j.biocon.2016.05.015

Meentemeyer RK, Dorning MA, Vogler JB et al (2015) Citizen science helps predict risk of emerging infectious disease. Front Ecol Environ 13:189-194. https://doi.org/10.1890/ 140299

Miller-Rushing A, Primack R, Bonney R (2012) The history of public participation in ecological research. Front Ecol Environ 10:285-290. https://doi.org/10.1890/110278

Mozilla Foundation, Peer 2 Peer University, MacArthur Foundation (2012) Open badges for lifelong learning. Working document. https://wiki.mozilla.org/images/5/59/ OpenBadges-Working-Paper_012312.pdf. Accessed 20 May 2021

Nowak MM, Dziób K, Ludwisiak L, Chmiel J (2020) Mobile GIS applications for environmental field surveys: a state of the art. Glob Ecol Conserv e01089. https://doi.org/10. 1016/j.gecco.2020.e01089

O’Brien L, Townsend M, Ebden M (2008) Environmental volunteering: motivations, barriers and benefits. Report to the Scottish Forestry Trust and Forestry Commission. Farnham, Surrey

O'Brien L, Townsend M, Ebden M (2010) Doing something positive: volunteers' experiences of the well-being benefits derived from practical conservation activities in nature. Voluntas 21:525-545. https://doi.org/10.1007/s11266010-9149-1

Odenwald SF (2020) A citation study of earth science projects in citizen science. PLoS ONE 15(7):e0235265. https://doi. org/10.1371/journal.pone.0235265

Phillips T, Porticella N, Constas M, Bonney R (2018) A framework for articulating and measuring individual learning outcomes from participation in citizen science. Citiz Sci Theory Pr 3(2):3. https://doi.org/10.5334/cstp.126

Pocock MJO, Roy HE, Fox R et al (2017) Citizen science and invasive alien species: predicting the detection of the oak processionary moth Thaumetopoea processionea by moth recorders. Biol Conserv 208:146-154. https://doi.org/10. 1016/j.biocon.2016.04.010

Pocock MJO, Roy HE, August T et al (2019) Developing the global potential of citizen science: assessing opportunities that benefit people, society and the environment in East Africa. J Appl Ecol 56:274-281. https://doi.org/10.1111/ 1365-2664.13279

Pocock MJO, Marzano M, Bullas-Appleton E et al (2020) Ethical dilemmas when using citizen science for early detection of invasive tree pests and diseases. Manag Biol Invasions 11:720-732. https://doi.org/10.3391/mbi.2020. 11.4.07

Potter C, Harwood T, Knight J, Tomlinson I (2011) Learning from history, predicting the future: the UK Dutch elm disease outbreak in relation to contemporary tree disease threats. Phil Trans R Soc B366:1966-1974. https://doi.org/ 10.1098/rstb.2010.0395

Riesch H, Potter C (2014) Citizen science as seen by scientists: methodological, epistemological and ethical dimensions. Public Underst Sci 23:107-120. https://doi.org/10.1177/ 0963662513497324

Roy HE, Pocock MJO, Preston CD et al (2012) Understanding citizen science and environmental monitoring: Final report on behalf of UK Environmental Observation Framework.
NERC Centre for Ecology \& Hydrology and Natural History Museum. https://www.ceh.ac.uk/sites/default/files/ citizensciencereview.pdf. Accessed 20 May 2021

Sansford CE (2013) Pest Risk Analysis for Hymenoscyphus pseudoalbidus (anamorph Chalara fraxinea) for the UK and the Republic of Ireland. Forestry Commission.https:// secure.fera.defra.gov.uk/phiw/riskRegister/ downloadExternalPra.cfm?id=3848

Schade S, Pelacho M, van Noordwijk CGE et al (2021) Citizen science and policy. In: Vohlan, K, Land-Zandstra A, Ceccaroni L et al (eds) The science of citizen science, Springer International Publishing. https://doi.org/10.1007/ 978-3-030-58278-4

Shirk JL, Ballard HL, Wilderman CC et al (2012) Public participation in scientific research: a framework for deliberate design. Ecol Soc 17(2):29. https://doi.org/10.5751/ES04705-170229

Singh NJ, Danell K, Edenius L, Ericsson G (2014) Tackling the motivation to monitor: Success and sustainability of a participatory monitoring program. Ecol Soc 19(4):7. https://doi.org/10.5751/ES-06665-190407 8 pp.

Skarlatidou A, Suškevičs M, Göbel C et al (2019) The value of stakeholder mapping to enhance co-creation in citizen science initiatives. Citiz Sci Theory Pr 4(1):24. https://doi. org/10.5334/cstp. 226

Slawson DD, Moffat AJ (2020) How effective are citizen scientists at contributing to government tree health public engagement and surveillance needs - an analysis of the UK Open Air Laboratories (OPAL) survey model. Insects 11:550. https://doi.org/10.3390/insects 11090550

Stepenuck KF, Green LT (2015) Individual- and communitylevel impacts of volunteer environmental monitoring: a synthesis of peer-reviewed literature. Ecol Soc 20(3):19. https://doi.org/10.5751/ES-07329-200319

Tellis WM (1997) Introduction to case study. The Qualitative Report 3(2):1-14. https://doi.org/10.46743/2160-3715/ 1997.2024

Toomey AH, Domroese MC (2013) Can citizen science lead to positive conservation attitudes and behaviors? Hum Ecol Rev 20(1):50-62. www.jstor.org/stable/24707571. Accessed 20 May 2021

Unell J, Castle R (2012) Developing sustainable volunteering within the Natural Connections Demonstration Project: A review of evidence. Natural England. Commissioned Report NECR096. Available at http://publications. naturalengland.org.uk/publication/1988713. Accessed 8 August 2021

Urquhart J, Potter C, Barnett J et al (2017) Awareness, concern and willingness to adopt biosecure behaviours: public perceptions of invasive tree pests and pathogens in the UK. Biol Invasions 19:2567-2582. https://doi.org/10.1007/ s10530-017-1467-4

van der Wal R, Sharma N, Mellish C et al (2016) The role of automated feedback in training and retaining biological recorders for citizen science. Conserv Biol 30(3):550-561. https://doi.org/10.1111/cobi.12705

Vohland K, Land-Zandstra A, Ceccaroni L et al (eds) (2021) The science of citizen science. Springer Nature, Switzerland

Webber J (2010) Pest risk analysis and invasion pathways for plant pathogens. NZ J For Sci 40 suppl:S45-S56. https:// doi.org/10.1016/j.envsci.2019.09.002 
Wehn U, Almomani A (2019) Incentives and barriers for participation in community-based environmental monitoring and information systems: A critical analysis and integration of the literature. Environ Sci Pol 101:341-357. https:// doi.org/10.1016/j.envsci.2019.09.002

West S, Pateman R (2016) Recruiting and retaining participants in citizen science: what can be learned from the volunteering literature? Citiz Sci Theory Pr 1(2):15. https://doi. org/10.5334/cstp.8 10 pp.

Yin RK (1984) Case Study Research: Design and Methods. Sage Publications, Beverly Hills
Young BE, Dodge N, Hunt PD, Ormes M, Schlesinger MD, Shaw HY (2019) Using citizen science data to support conservation in environmental regulatory contexts. Biol Conserv 237:57-62. https://doi.org/10.1016/j.biocon. 2019.06.016

Publisher's Note Springer Nature remains neutral with regard to jurisdictional claims in published maps and institutional affiliations. 